\title{
Environmental regulation of glycosidase and peptidase production by Streptococcus gordonii FSS2
}

\author{
Derek W. S. Harty, ${ }^{1}$ John A. Mayo, ${ }^{2}+$ Simon L. Cook ${ }^{1}$ \\ and Nicholas $A$. Jacques ${ }^{1}$
}

1 Institute of Dental Research, United Dental Hospital, Surry Hills, NSW 2010, Australia

2 Department of Microbiology, Immunology and Parasitology, Louisiana State University Medical Center, New Orleans, LA USA

Author for correspondence: Derek W. S. Harty. Tel: +6129293 3348. Fax: +61292933368. e-mail:derekh@dentistry.usyd.edu.au

The synthesis of cell-associated and secreted proteins by Streptococcus gordonii FSS2, an infective endocarditis (IE) isolate, was influenced by both environmental pH and carbon source. Controlling the pH at 7.5 in stirred batch cultures showed that cell-associated and secreted protein concentrations were increased during late exponential and stationary phase by $68 \%$ and $125 \%$, respectively, compared with similar cultures without pH control. The expression of five glycosidase and eight peptidase activities were examined using fluorogen-labelled synthetic substrates. Enzyme activities were significantly down-regulated during exponential growth, increasing during stationary phase $(P<0.01)$ whether the culture $\mathrm{pH}$ was controlled at $\mathrm{pH} 7.5$ or allowed to fall naturally to $\mathrm{pH} 4 \cdot 4$. Culture-supernatant activities were significantly increased $(P<0.05)$ when the $\mathrm{pH}$ was maintained at 6.0 or 7.5 , indicating modulation of enzyme activity by $\mathrm{pH}$. Growth under nitrogenlimitation/glucose-excess conditions resulted in a significant repression of cellassociated glycosidase activities $(P<0.01)$, whilst in the supernatant, activities were generally reduced. The expression of peptidase activities in the culture supernatant did not significantly change. The results suggest a possible role for catabolite repression by glucose in regulating enzyme expression. When $S$. gordonii FSS2 was cultured with $\mathbf{5 0 \%}$ (v/v) added heat-inactivated foetal bovine serum, several cell-associated enzyme activities increased initially but were then reduced as the culture time was extended to $116 \mathrm{~h}$. Culturesupernatant enzyme activities ( $\boldsymbol{N}$-acetyl- $\beta$-D-glucosaminidase, $\boldsymbol{N}$-acetyl- $\beta$-Dgalactosaminidase, thrombin, Hageman factor, collagenase and chymotrypsin), however, were significantly increased $(P<0.01)$ over the same time period. The findings indicated that most of the important glycosidases synthesized by S. gordonii FSS2 were down-regulated by acid growth conditions and may also be subject to catabolite repression by glucose but conversely may be upregulated by growth in serum. These results may have implications for streptococcal growth in an IE vegetation and in the mouth between meals or during sleep.

Keywords: Infective endocarditis, Streptococcus gordonii, pH, enzymes

\section{INTRODUCTION}

Streptococcus sanguis and Streptococcus gordonii, members of the Streptococcus mitis group (Whiley \& Beighton, 1998), are primary colonizers of the oral cavity where they form an important part of the microbial community that comprises healthy dental plaque. S. sanguis and S. gordonii, with other streptococci in the mitis group of organisms, are also major causative organisms of the disease infective endocarditis

†Present address: Department of Biochemistry and Molecular Biology, University of Georgia, Athens, GA, USA.

Abbreviations: 7-AMC, 7-amido-4-methylcoumarin; $\mathrm{Ca}$, activated protein $\mathrm{C}$; $\mathrm{CDM}$, chemically defined medium; FBS, foetal bovine serum; IE, infective endocarditis; 4-MU, 4-methyl-umbelliferyl; PAS, periodic acid/Schiff; Xa, activated protein X. 
(IE), where it is thought that poor dental hygiene can result in the streptococci entering the bloodstream from dental plaque. Once in the bloodstream, the streptococci have been shown to cause haemodynamic changes in the rabbit model of experimental endocarditis where intermittent electrocardiographic abnormalities and preventricular contractions are observed in the initial 3-7 min after infusion of the bacteria (Meyer et al., 1998). Blood catecholamine concentration, thrombocytopenia, the accumulation of platelets in the lungs and ventricular axis deviation also showed dose dependency (Meyer et al., 1998; Herzberg \& Meyer, 1996). Streptococcal species are also able to adhere to (Ke Gong et al., 1998) and aggregate platelets (Herzberg, 1996; Herzberg et al., 1992; Ford \& Douglas 1997; Manning et al. 1994a, b), as well as adhere to damaged areas of the heart valve, resulting in the formation of a platelet fibrin vegetation (Lowrance et al., 1988; Manning et al., 1994b).

Several studies have examined the enzymes produced by streptococci that enable them to metabolize complex molecules, mainly concentrating on the model glycoprotein, pig gastric mucin. Homer et al. (1996) examined the ability of Streptococcus oralis to synthesize sialidase and $\mathrm{N}$-acetylglucosaminidase, enzymes important in the metabolism of glycoproteins, and found that both were induced when grown in the presence of pig gastric mucin (Rafay et al., 1996). It has also been observed that growth in pig gastric mucin leads to higher levels of bacterial glycosidase activity, whilst some protease activities are repressed. Conversely, the presence of glucose represses glycosidase activity (Rafay et al., 1996; Beighton et al., 1995). Mayo et al. (1995) showed that $S$. gordonii FSS2 grown in a complex medium produced a variety of glycosidase and peptidase enzymes which were modulated by both growth rate and environmental $\mathrm{pH}$. Enzyme activities were generally higher at $\mathrm{pH} 6.5$ than at $5 \cdot 5$ or $7 \cdot 5$. The exception was thrombin-like activity which was found to be fivefold higher at more neutral $\mathrm{pH}$ than under more acidic conditions. Another activity, Hageman factor, was apparently subject to catabolite repression by glucose, as activity was threefold higher in cultures grown on galactose compared with those grown on glucose. Enzymes important for catabolism in S. gordonii FSS2 therefore seem to be regulated by environmental conditions.

The shift from a low oral $\mathrm{pH}$ to blood $\mathrm{pH}$ has been shown in $S$. gordonii to induce or up-regulate the expression of several genes including one, $m s r A$, which is involved in protection against oxidative stress and enhanced bacterial growth (Vriesema et al., 2000). In this work we investigate the effects of environmental $\mathrm{pH}$ and carbon source on the expression of cell-associated and secreted enzymes of $S$. gordonii grown in a fully defined medium.

\section{METHODS}

Bacterial strain. The streptococcal strain used in this work was originally isolated from an IE patient at Freeman Hospital, Newcastle-upon-Tyne, UK (Manning et al., 1994b; Mayo et al., 1995) and was at the time designated as S. sanguis FSS2. Recent taxonomic studies on streptococci (Whiley \& Beighton 1998) have indicated that the majority of $S$. sanguis isolates are unable to produce $\alpha$-L-fucosidase, $N$-acetyl- $\beta$-D-galactosaminidase, $N$-acetyl- $\beta$-D-glucosaminidase and alkaline phosphatase, whilst $S$. gordonii strains are generally able to produce these enzyme activities. The presence of these enzyme activities as well as taxonomic testing using the API ID32 strep test kit (bioMérieux Vitek) indicated that the streptococcal strain should be designated $S$. gordonii.

Culture media. S. gordonii FSS2 was stored as brain-heart infusion broth (Oxoid) $/ 20 \%$ (v/v) glycerol stocks at $-70{ }^{\circ} \mathrm{C}$ and was routinely grown on Columbia blood agar plates (Oxoid) with $5 \%(\mathrm{v} / \mathrm{v})$ horse blood. Batch cultures were grown on a filter-sterilized $(0 \cdot 2 \mu \mathrm{m}$ pore; Sartorius) chemically defined medium (CDM) modified from that described by Terleckyj et al. (1975) and Wittenberger et al. (1978), containing ( $\mathrm{mg} \mathrm{l}^{-1}$ unless stated otherwise): trisodium citrate, $250 ; \mathrm{NH}_{4} \mathrm{SO}_{4}, 600 ; \mathrm{CaCl}_{2} .2 \mathrm{H}_{2} \mathrm{O}, 20 ; \mathrm{MnSO}_{4} .4 \mathrm{H}_{2} \mathrm{O}, 11$; $\mathrm{MgSO}_{4} \cdot 7 \mathrm{H}_{2} \mathrm{O}, 700 ; \mathrm{FeSO}_{4} \cdot 7 \mathrm{H}_{2} \mathrm{O}, 18 ; \mathrm{Na}_{2} \mathrm{MoO}_{4} .2 \mathrm{H}_{2} \mathrm{O}$, $0 \cdot 15 ; \mathrm{NaCl}, 2000 ; \mathrm{NaHCO}_{3}, 500$; adenine, 20; guanine, 20; uracil, 20; thiamin, 8 ; pyridoxamine, 2 ; calcium pantothenate, 8 ; riboflavin, 8 ; nicotinamide, $4 ; p$-aminobenzoic acid, 0.4 ; biotin, $0 \cdot 2$; folic acid, $0 \cdot 2$; inositol, 2 ; thiamin, 2 ; L-glutamic acid, L-glycine and L-cysteine, $3 \mathrm{mM}$; L-arginine, L-lysine, Lisoleucine, L-leucine, L-methionine, L-tryptophan, L-tyrosine, L-histidine, L-proline, DL-alanine, L-aspartic acid, L-phenylalanine, L-asparagine, L-serine, $\mathrm{L}$-threonine, $\mathrm{L}$-valine and $\mathrm{L}$ glutamine all $1 \mathrm{mM} ; 30 \mathrm{mM}$ potassium phosphate buffer $\mathrm{pH}$ $7 \cdot 5 ; 0.5 \%(\mathrm{w} / \mathrm{v})$ glucose $(27.8 \mathrm{mM})$. The medium was brought to $\mathrm{pH} 7.5$ by the addition of $5 \mathrm{M} \mathrm{KOH}$. All chemicals were of analytical grade and were purchased from either Sigma or Merck. In one series of experiments, $50 \%(\mathrm{v} / \mathrm{v})$ foetal bovine serum (FBS; Commonwealth Serum Laboratories), heated at $80^{\circ} \mathrm{C}$ for $30 \mathrm{~min}$ to inactivate serum-enzyme activities, was added to CDM devoid of glucose.

Growth conditions. S. gordonii FSS2 was grown at $37^{\circ} \mathrm{C}$ as a $100 \mathrm{ml}$ stirred, pH-controlled batch culture gassed with $5 \%$ $(\mathrm{v} / \mathrm{v}) \mathrm{CO}_{2} / 95 \%(\mathrm{v} / \mathrm{v}) \mathrm{N}_{2}$ at a rate of $50 \mathrm{ml} \mathrm{min}^{-1}$. The $\mathrm{pH}$ was controlled by automatic addition of a mixture of $2 \mathrm{M}$ $\mathrm{NaOH}$ and $2 \mathrm{M} \mathrm{KOH}$ (to avoid changes in the sodium: potassium ratio of the medium during growth; Pitty \& Jacques, 1989). Batch cultures were inoculated at $15 \%(\mathrm{v} / \mathrm{v})$ from a $20 \mathrm{ml}$ static batch culture grown for $18 \mathrm{~h}$ in CDM. In some experiments, CDM was modified to provide carbonexcess/nitrogen-limited growth conditions by removing the ammonium sulphate and adding one-third the concentration of amino acids ( $1 \mathrm{mM}$ glutamic acid, glycine and cysteine; $0.33 \mathrm{mM}$ all other amino acids). This resulted in residual glucose $\left[0.93 \mathrm{mg} \mathrm{ml}^{-1}(5 \cdot 2 \mathrm{mM})\right]$ being detected in the medium at stationary phase.

Bacteria were harvested by centrifugation $\left(27000 \mathrm{~g}, 4^{\circ} \mathrm{C}\right.$, $5 \mathrm{~min}$ ), washed three times in $50 \mathrm{mM}$ potassium phosphate buffer $\mathrm{pH} 7.5$ containing $0.02 \%(\mathrm{w} / \mathrm{v})$ sodium azide and resuspended to an $\mathrm{OD}_{600} 1 \cdot 00 \pm 0 \cdot 05$. All determinations of cell-associated protein concentration were made at $\mathrm{OD}_{600}$. Supernatants were filtered through $0.2 \mu \mathrm{m}$ pore membranes (Sartorius) prior to assaying for enzyme activity. In some experiments, bacteria were resuspended in $50 \mathrm{mM}$ citrate/ phosphate buffer at $\mathrm{pH} 4 \cdot 0, \mathrm{pH} 5 \cdot 0$ or $\mathrm{pH} 6.0$ and incubated at $37^{\circ} \mathrm{C}$ for $2 \mathrm{~h}$ before being recentrifuged $\left(27000 \mathrm{~g}, 4^{\circ} \mathrm{C}, 5 \mathrm{~min}\right)$ and resuspended in $50 \mathrm{mM}$ potassium phosphate buffer $\mathrm{pH}$ $7 \cdot 5$ prior to assaying for enzyme activities.

The ability of $S$. gordonii FSS2 to utilize FBS as a source of nutrients was determined in $\mathrm{pH}$-controlled stirred cultures by the addition of an equal volume of heat-inactivated FBS to the 
defined medium devoid of glucose. After treatment, the only residual enzyme activities in FBS were thrombin [5.7 (4.1$\left.7 \cdot 4) \mathrm{nmol} \mathrm{h}^{-1}(100 \mathrm{ml} \text { culture })^{-1}\right]$ and Hageman factor $[9 \cdot 8$ $(8 \cdot 1-11 \cdot 4) \mathrm{nmol} \mathrm{h}^{-1}(100 \mathrm{ml} \text { culture })^{-1}$ ] representing $0 \cdot 2 \%$ and $0.02 \%$, respectively, of the initial activities prior to heating at $80^{\circ} \mathrm{C}$. Bacterial growth was monitored spectrophotometrically at $\mathrm{OD}_{600}$ and by the number of viable cells in $1 \mathrm{ml}$ culture samples after being sonicated $\left(10^{\circ} \mathrm{C}, 5 \mathrm{~min}, 130 \mathrm{~W}\right)$ in a cup horn (Branson model 450 sonifier, Branson Ultrasonics) to break up aggregates of bacteria before being diluted and plated on Columbia $5 \%(\mathrm{v} / \mathrm{v})$ horse-blood agar.

A partial separation of the 'fibrous' precipitate from streptococcal cells grown on FBS was achieved by a slow-speed centrifugation $\left(500 \mathrm{~g}, 22{ }^{\circ} \mathrm{C}, 5 \mathrm{~min}\right)$. Examination by light microscopy of the pellet after centrifugation indicated that few bacterial cells were present.

Enzyme assays. Four glycosidase and eight peptidase activities were measured using a range of synthetic substrates attached to the fluorogens, 4-methylumbelliferone or 7-amido-4methylcoumarin (7-AMC), that were purchased from Sigma. The substrates (with the activity they detected shown in parentheses) were: 4-methylumbelliferyl (4-MU) - $\beta$-D-glucoside ( $\beta$-D-glucosidase); 4-MU- $\beta$-D-galactoside ( $\beta$-D-galactosidase); $\quad 4-\mathrm{MU}-N$-acetyl- $\beta$-D-glucosaminide $\quad(N$-acetyl- $\beta$-Dglucosaminidase); 4-MU-N-acetyl- $\beta$-D-galactosaminide $(N$ acetyl- $\beta$-D-galactosaminidase); $N$-tert-butoxycarbonyl-ValPro-Arg-7-AMC (thrombin); N-tert-butoxycarbonyl-Leu-SerThr-Arg-7-AMC [activated protein $\mathrm{C}(\mathrm{Ca})$ ]; N-tert-carbobenzyloxy-Phe-Arg-7-AMC (kallikrein); N-tert-carbobenzyloxy-Lys-7-AMC (Hageman factor); N-tert-butoxycarbonylIle-Glu-Gly-Arg-7-AMC [activated protein X (Xa)]; N-tertbutoxycarbonyl-Glu-Lys-Lys-7-AMC (plasmin); N-succinylLeu-Leu-Val-Tyr-7-AMC (chymotrypsin); and N-succinylGly-Pro-Leu-Gly-Pro-7-AMC (collagenase) (Mayo et al., 1995; Oakey et al., 1995). All substrates were dissolved in a minimal amount of dimethylsulphoxide and then diluted to $100 \mu \mathrm{g} \mathrm{ml}^{-1}$ in $50 \mathrm{mM}$ potassium phosphate buffer $\mathrm{pH} 7 \cdot 5$ containing $0.02 \%(\mathrm{w} / \mathrm{v})$ sodium azide. Enzyme assays were performed in duplicate at room temperature $\left(18-20^{\circ} \mathrm{C}\right)$ using a Perkin-Elmer Luminescence spectrometer LS50-B with a microtitre plate assembly using white 96 -well microtitre plates (Perkin-Elmer). The assay volume of $200 \mu \mathrm{l}$ consisted of $50 \mu \mathrm{l}$ substrate, $50 \mu \mathrm{l}$ bacterial cells or $10 \mu \mathrm{l}$ culture supernatant diluted to $150 \mu \mathrm{l}$ with $50 \mathrm{mM}$ potassium phosphate buffer $\mathrm{pH}$ 7.5. The controls contained $50 \mu \mathrm{l}$ substrate and $150 \mu \mathrm{l} 50 \mathrm{mM}$ potassium phosphate buffer $\mathrm{pH} 7 \cdot 5$. Fluorescence readings were taken at $0,10,20,30,40,50,60$ and $120 \mathrm{~min}$ and at $24 \mathrm{~h}$. The maximum rate of release of fluorogen was determined and calculated from a standard curve of authentic 4-MU or 7AMC and expressed as specific activity for cell-associated enzymes $\left[\mathrm{nmol} \mathrm{h}^{-1}(\mathrm{mg} \text { protein })^{-1}\right]$ or total activity for culturesupernatant activities $\left[\mathrm{nmol}^{-1} \mathrm{~h}^{-1}(100 \mathrm{ml} \text { culture })^{-1}\right]$.

Enzyme synthesis. To confirm that de novo enzyme synthesis was occurring, cells from a $20 \mathrm{ml}$ CDM static batch culture containing $30 \mathrm{mM}$ potassium phosphate buffer $\mathrm{pH} 7.5$ and grown for $18 \mathrm{~h}$ were harvested as above and resuspended in $5 \mathrm{ml}$ phosphate buffered saline. A portion of the resuspended cells was reserved to determine enzyme activities. Of the remaining cells, $1 \mathrm{ml}$ was inoculated into duplicate prewarmed CDM cultures containing $100 \mathrm{mM}$ potassium phosphate buffer $\mathrm{pH} 7 \cdot 5$, or duplicate CDM cultures supplemented with $100 \mathrm{mM}$ potassium phosphate buffer $\mathrm{pH} 7 \cdot 5$ and $50 \%$ $(\mathrm{v} / \mathrm{v})$ heat-inactivated FBS. Increasing the concentration of phosphate buffer raised the terminal $\mathrm{pH}$ of the culture. Chloramphenicol was added to a final concentration of $100 \mu \mathrm{g} \mathrm{ml}^{-1}$ to one of each of the duplicate cultures to inhibit protein synthesis. The cultures were incubated for $6 \mathrm{~h}$ in an anaerobic jar as described above before being harvested by centrifugation $\left(27000 \mathrm{~g}, 4^{\circ} \mathrm{C}, 5 \mathrm{~min}\right)$ and washed three times in $50 \mathrm{mM}$ potassium phosphate buffer $\mathrm{pH} 7.5$ containing $0.02 \%(\mathrm{w} / \mathrm{v})$ sodium azide. The cells were finally resuspended to an $\mathrm{OD}_{600} 1 \cdot 00 \pm 0 \cdot 05$ for determination of enzyme activities. To confirm that chloramphenicol was inhibiting protein synthesis, static batch cultures of $S$. gordonii were grown in CDM supplemented with $185 \mathrm{kBq}\left[{ }^{3} \mathrm{H}\right]$ leucine (Amersham Life Sciences). After harvesting and washing, the level of incorporation of $\left[{ }^{3} \mathrm{H}\right]$ leucine into the cells was determined using a Packard 1500 Tricarb Liquid scintillation analyser (Canberra Packard).

Analytical procedures. The concentration of bacterial cellassociated proteins (at $\mathrm{OD}_{600} 1 \cdot 00 \pm 0.05$ ) and the protein concentration in the culture supernatant were determined by the Pierce Coomassie Protein Plus Assay Reagent (Pierce) using bovine serum albumin as the standard. The concentration of residual glucose in CDM and in serum was determined using a glucose oxidase test kit (Sigma). Statistical analysis, Friedman non-parametric repeated-measures test, two-tailed, was carried out using the statistical program Instat v2.02 (Graphpad Inc.). SDS-PAGE analysis of FBS culture components was carried out on duplicate $10 \%$ gels (Laemmli, 1970). One gel was stained for protein with Gelcode Blue Coomassie blue (Pierce) and the other stained for carbohydrate [periodic acid/Schiff (PAS) stain] using the method described by Pitty et al. (1989). Protein molecular masses were estimated using Bio-Rad broad range molecular mass markers.

\section{RESULTS}

\section{Effect of pH control on the expression of enzyme activities}

To examine the effect of $\mathrm{pH}$ on growth and protein expression by $S$. gordonii FSS2, $100 \mathrm{ml}$ stirred batch cultures were grown with and without $\mathrm{pH}$ control. Cultures grown without $\mathrm{pH}$ control (Fig. 1a) had a rapid reduction in $\mathrm{pH}$ after a lag period of approximately $1 \mathrm{~h}$. By the onset of stationary phase the culture $\mathrm{pH}$ had fallen to $\mathrm{pH} 4.7$ and by late stationary phase $(7 \mathrm{~h})$ had fallen further to $\mathrm{pH} 4 \cdot 4$. Over the whole period of growth, the amount of both cell-associated and culturesupernatant protein varied very little. The cellassociated protein concentration at the first sample point $(1.5 \mathrm{~h})$ was measured as $86.3 \pm 4.0 \mu \mathrm{g} \mathrm{ml}^{-1}$ and as $79 \cdot 4 \pm 0.5 \mu \mathrm{g} \mathrm{ml}^{-1}$ by late stationary phase. Over the same period, the protein concentration of the culture supernatant increased by only $28 \cdot 8 \%$. In contrast, when the $\mathrm{pH}$ of the culture was controlled at $\mathrm{pH} 7 \cdot 5$ (Fig. 1b), the cell-associated protein concentration increased marginally during the exponential phase of growth but increased by $68.2 \%$ once the culture had entered stationary phase. Similarly, the concentration of protein observed in the culture supernatant increased gradually during exponential growth but rose rapidly in stationary phase to give an overall increase of $125 \%$ over that observed during the lag phase of growth. When the $\mathrm{pH}$ was set at an intermediate level $(\mathrm{pH} 6.5)$, the cellassociated protein concentration was unchanged between exponential phase $\left(63.7 \pm 0.7 \mu \mathrm{g} \mathrm{ml}^{-1}\right)$ and stationary phase $\left(63 \cdot 7 \pm 2 \cdot 4 \mu \mathrm{g} \mathrm{ml}^{-1}\right)$. Culture-supernatant protein concentration, in contrast, increased 

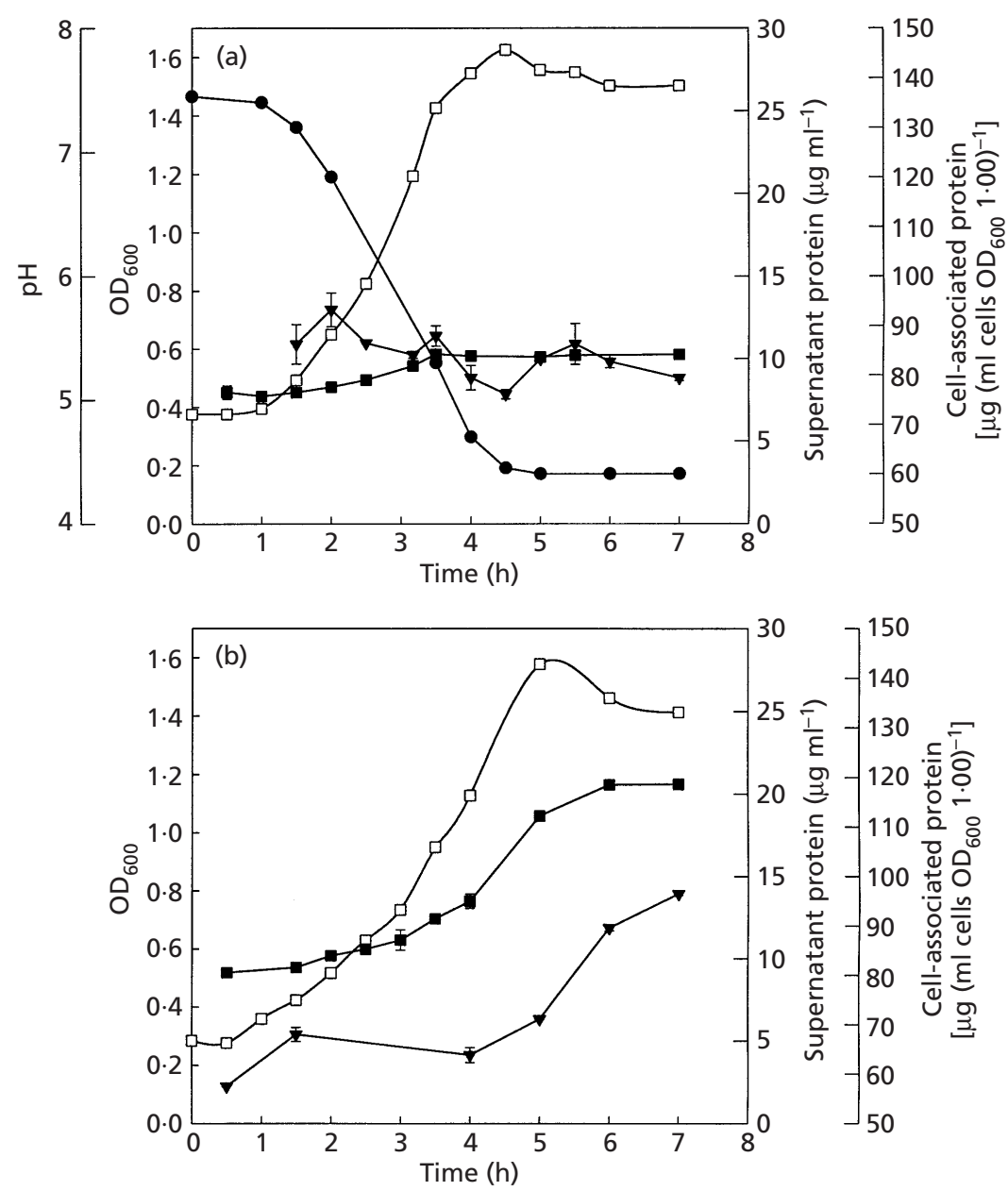

Fig. 1. Cell-associated and secreted protein production by $S$. gordonii FSS2 grown (a) without $\mathrm{pH}$ control and (b) at $\mathrm{pH} 7 \cdot 5$. 0, $\mathrm{pH} ; \square, \mathrm{OD}_{600} ; \square$, supernatant protein concentration $\left(\mu \mathrm{g} \mathrm{ml}^{-1}\right) ; \boldsymbol{\nabla}$, cell-associated protein concentration $\left[\mu \mathrm{g}\left(\mathrm{ml}\right.\right.$ cells $\mathrm{OD}_{600}$ $1 \cdot 00)^{-1}$. Values represent the mean and bars show standard deviation $(n=2)$.

Table 1. Cell-associated enzyme specific activities $\left[\mathrm{nmol} \mathrm{h}^{-1}(\mathrm{mg} \text { protein })^{-1}\right]$ of $S$. gordonii FSS2 at exponential and stationary phases

ND, Not detected $\left[<2 \mathrm{nmol} \mathrm{h}^{-1}(\mathrm{mg} \text { protein })^{-1}\right]$. Values are the mean of two assays; replicates all showed less than twofold difference.

\begin{tabular}{|c|c|c|c|c|c|c|}
\hline Enzyme & $\begin{array}{c}\text { No pH control, } \\
\text { exponential } \\
\text { phase }\end{array}$ & $\begin{array}{l}\text { No pH control, } \\
\text { stationary phase }\end{array}$ & $\begin{array}{c}\text { pH } 7 \cdot 5, \\
\text { exponential } \\
\text { phase }\end{array}$ & $\begin{array}{l}\mathrm{pH} 7 \cdot 5, \\
\text { stationary } \\
\text { phase }\end{array}$ & $\begin{array}{l}\text { pH } 6 \cdot 5, \\
\text { stationary } \\
\text { phase }\end{array}$ & $\begin{array}{c}\text { Nitrogen- } \\
\text { limited/glucose-excess, } \\
\text { stationary phase }\end{array}$ \\
\hline$\beta$-D-Galactosidase & ND & $27 \cdot 7$ & $7 \cdot 5$ & $66 \cdot 8$ & $11 \cdot 9$ & $\mathrm{ND}$ \\
\hline $\begin{array}{l}N \text {-Acetyl- } \beta \text {-D- } \\
\text { glucosaminidase }\end{array}$ & $7 \cdot 3$ & $51 \cdot 3$ & $20 \cdot 7$ & $218 \cdot 1$ & $123 \cdot 3$ & $7 \cdot 8$ \\
\hline $\begin{array}{l}N \text {-Acetyl- } \beta \text {-D- } \\
\text { galactosaminidase }\end{array}$ & ND & $9 \cdot 7$ & $3 \cdot 3$ & $42 \cdot 6$ & $20 \cdot 6$ & ND \\
\hline$\beta$-D-Glucosidase & ND & $46 \cdot 4$ & $11 \cdot 9$ & $352 \cdot 2$ & $150 \cdot 7$ & $\mathrm{ND}$ \\
\hline Thrombin & ND & $20 \cdot 2$ & $7 \cdot 9$ & $97 \cdot 9$ & $35 \cdot 4$ & $14 \cdot 2$ \\
\hline Plasmin & ND & $2 \cdot 5$ & ND & ND & $3 \cdot 9$ & $5 \cdot 2$ \\
\hline Kallikrein & ND & $20 \cdot 3$ & $5 \cdot 5$ & ND & $12 \cdot 0$ & ND \\
\hline Hageman & 1701 & $2353 \cdot 7$ & $934 \cdot 3$ & $962 \cdot 3$ & $1863 \cdot 0$ & $279 \cdot 1$ \\
\hline Collagenase & $33 \cdot 5$ & $23 \cdot 4$ & $24 \cdot 9$ & $27 \cdot 5$ & $36 \cdot 9$ & $37 \cdot 7$ \\
\hline $\mathrm{Ca}$ & $7 \cdot 7$ & $38 \cdot 5$ & $12 \cdot 9$ & $29 \cdot 6$ & $46 \cdot 0$ & $37 \cdot 5$ \\
\hline $\mathrm{Xa}$ & $12 \cdot 5$ & $9 \cdot 0$ & $6 \cdot 7$ & $6 \cdot 9$ & $11 \cdot 9$ & $4 \cdot 2$ \\
\hline Chymotrypsin & $4 \cdot 5$ & $32 \cdot 0$ & $15 \cdot 0$ & $15 \cdot 7$ & $64 \cdot 1$ & $34 \cdot 9$ \\
\hline
\end{tabular}


Table 2. Enzyme total activities in culture supernatant [nmol h $\mathrm{h}^{-1}(100 \mathrm{ml} \text { culture })^{-1}$ ] of S. gordonii FSS2 at exponential and stationary phase

ND, Not detected $\left[<2 \mathrm{nmol} \mathrm{h}^{-1}(100 \mathrm{ml} \text { culture })^{-1}\right]$. Values are the mean of two assays; replicates all showed less than twofold difference except where indicated.

\begin{tabular}{|c|c|c|c|c|c|c|}
\hline Enzyme & $\begin{array}{c}\text { No pH control, } \\
\text { exponential } \\
\text { phase }\end{array}$ & $\begin{array}{l}\text { No pH control, } \\
\text { stationary phase }\end{array}$ & $\begin{array}{c}\mathrm{pH} 7 \cdot 5, \\
\text { exponential } \\
\text { phase }\end{array}$ & $\begin{array}{c}\mathrm{pH} 7 \cdot 5, \\
\text { stationary } \\
\text { phase }\end{array}$ & $\begin{array}{l}\mathrm{pH} 6 \cdot 5, \\
\text { stationary } \\
\text { phase }\end{array}$ & $\begin{array}{c}\text { Nitrogen- } \\
\text { limited/glucose- } \\
\text { excess, stationary } \\
\text { phase }\end{array}$ \\
\hline$\beta$-D-Galactosidase & ND & ND & ND & $14 \cdot 0$ & ND & ND \\
\hline $\begin{array}{l}N \text {-Acetyl- } \beta \text {-D- } \\
\text { glucosaminidase }\end{array}$ & ND & ND & ND & $190 \cdot 3$ & ND & ND \\
\hline $\begin{array}{l}N \text {-Acetyl- } \beta \text {-D- } \\
\text { galactosaminidase }\end{array}$ & ND & ND & ND & $26 \cdot 4$ & ND & ND \\
\hline$\beta$-D-Glucosidase & ND & ND & ND & ND & ND & $\mathrm{ND}$ \\
\hline Thrombin & ND & ND & $14 \cdot 8$ & $26 \cdot 5$ & $2 \cdot 2$ & $7 \cdot 5$ \\
\hline Plasmin & ND & ND & $\mathrm{ND}$ & ND & ND & $\mathrm{ND}$ \\
\hline Kallikrein & ND & ND & $\mathrm{ND}$ & $5 \cdot 1$ & $\mathrm{ND}$ & ND \\
\hline Hageman & ND & $120 \cdot 4(75 \cdot 5-165)$ & $95 \cdot 6$ & $662 \cdot 1$ & $112 \cdot 7$ & $1410 \cdot 8$ \\
\hline Collagenase & ND & $14 \cdot 5(0 \cdot 0-29 \cdot 0)$ & $58 \cdot 8$ & $70 \cdot 0$ & $21 \cdot 7$ & $81 \cdot 3$ \\
\hline $\mathrm{Ca}$ & ND & ND & $23 \cdot 5$ & $43 \cdot 5$ & $2 \cdot 4$ & $38 \cdot 3$ \\
\hline $\mathrm{Xa}$ & ND & ND & $7 \cdot 1$ & $2 \cdot 3$ & ND & $\mathrm{ND}$ \\
\hline Chymotrypsin & ND & ND & $30 \cdot 4$ & $17 \cdot 7$ & $19 \cdot 2$ & $31 \cdot 3$ \\
\hline
\end{tabular}

from $7 \cdot 6 \pm 0 \cdot 1 \mu \mathrm{g} \mathrm{ml} l^{-1}$ in exponential phase to $12 \cdot 7 \pm$ $0 \cdot 1 \mu \mathrm{g} \mathrm{ml}^{-1}$ at stationary phase (a $67 \%$ increase) (data not shown).

\section{Effect of pH and carbon source on glycosidase and peptidase activities}

Cell-associated and culture-supernatant enzyme activities were determined at both mid-exponential and stationary phases. The cell-associated specific activities were significantly increased in stationary phase over those measured in mid-exponential phase in both nonpH-controlled $(P=0.007)$ and $\mathrm{pH} 7.5$ cultures $(P=$ 0.012) (Table 1). Cell-associated enzyme activities at stationary phase were not significantly different $(P>$ $0.05)$ between any of the growth conditions. Glucoseexcess/nitrogen-limitation conditions at stationary phase (Table 1 ) resulted in a significant reduction in cellassociated glycosidase activities when compared with cells grown at $\mathrm{pH} 7.5(P<0.01)$ while there was no significant change in the peptidase activities (Table 1 ).

To compare the enzyme activities in the culture supernatant for all the culture conditions, the total enzyme activities for the entire $100 \mathrm{ml}$ culture $\left[\mathrm{nmol} \mathrm{h}{ }^{-1}(100 \mathrm{ml}\right.$ culture volume $)^{-1}$ ] were calculated. In the absence of $\mathrm{pH}$ control, no activities were found at mid-exponential phase and only a very reduced level of both Hageman factor and collagenase activity was detected in stationary phase (Table 2 ). In cultures controlled at $\mathrm{pH} 7 \cdot 5$, none of the glycosidase activities was detected in mid-exponential phase whilst all the peptidase activities with the exception of plasmin and kallikrein were detected (Table 2). In stationary phase at $\mathrm{pH} 7 \cdot 5$, however, all activities with the exceptions of plasmin and $\beta$-Dglucosidase were detected and were significantly increased in comparison with mid-exponential-phase activities $(P=0.03)$ and with the stationary phase no $\mathrm{pH}$ control activities $(P<0 \cdot 01)$ (Table 2$)$.

To confirm that de novo protein synthesis was responsible for the increase in protein expression, duplicate cultures were incubated in the presence or absence of $100 \mu \mathrm{g}$ chloramphenicol $\mathrm{ml}^{-1}$. When compared with the activities present in the inoculum, the accumulation of enzyme activities was significantly reduced by the addition of chloramphenicol in the presence $(P<0.001)$ or absence $(P<0.05)$ of $50 \%(\mathrm{v} / \mathrm{v})$ FBS. Inhibition of protein synthesis by chloramphenicol was confirmed by the reduction of the incorporation of $\left[{ }^{3} \mathrm{H}\right]$ leucine into the cell. In the presence of chloramphenicol, incorporation of radioactivity into $S$. gordonii cells was reduced by $99.7 \%$ compared with control cells grown in the absence of chloramphenicol (data not shown).

\section{Effect of glucose-excess/nitrogen-limited conditions on enzyme activities}

At stationary phase, in cultures grown under glucose excess/nitrogen limitation at $\mathrm{pH} 7 \cdot 5$, the cell-associated protein concentration $\left(50 \cdot 1 \pm 0 \cdot 3 \mu \mathrm{g} \mathrm{ml}^{-1}\right)$ was approximately $50 \%$ of the value for the other culture conditions. Culture-supernatant protein concentration (19.9 \pm $0 \cdot 1 \mu \mathrm{g} \mathrm{ml}^{-1}$ ) was similar to the $\mathrm{pH} 7 \cdot 5$ culture grown on 


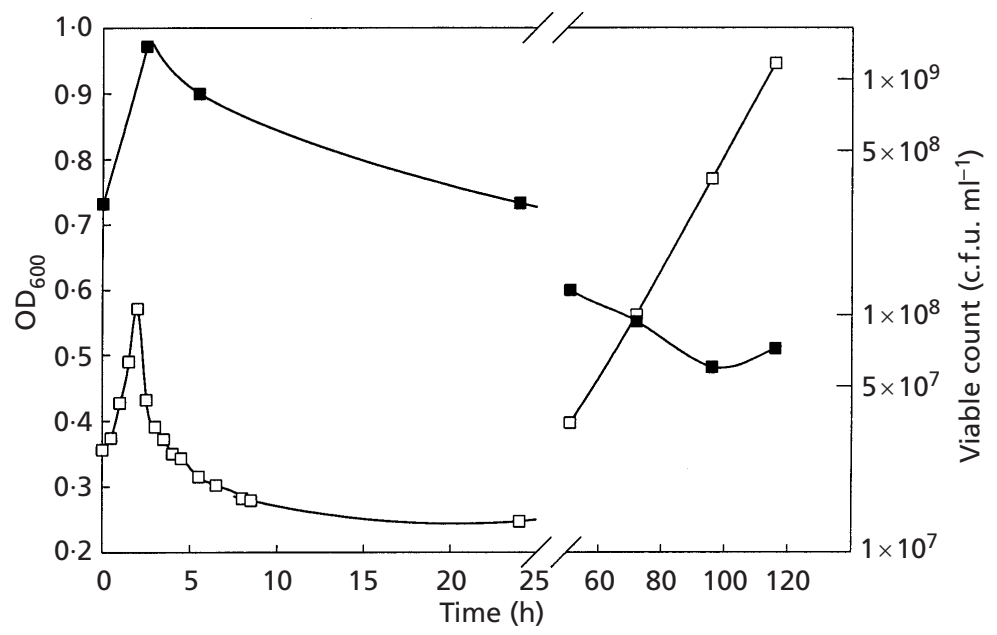

Fig. 2. Streptococcus gordonii FSS2 growth curve on $50 \%(\mathrm{v} / \mathrm{v}) \mathrm{FBS} \mathrm{pH} 7 \cdot 5 . \square, \mathrm{OD}_{600} ; \mathbf{\square}$, viable count (c.f.u. $\mathrm{ml}^{-1}$ ).

CDM but nearly double the concentration of cultures grown with no $\mathrm{pH}$ control or at $\mathrm{pH} 6.5$ on CDM. Cellassociated and supernatant glycosidase activities were undetectable, whilst peptidase activities were not significantly different from the other culture conditions (Tables 1 and 2).

\section{Effect of incubating cells in various pH buffers}

Washed cell suspensions of $S$. gordonii were incubated at $37^{\circ} \mathrm{C}$ in $50 \mathrm{mM}$ citrate/phosphate buffer at $\mathrm{pH} 4 \cdot 0$, 5.0 or 6.0 for $2 \mathrm{~h}$. Incubation at $\mathrm{pH} 4.0$ resulted in the total loss of measurable activity for all enzymes except $N$-acetyl- $\beta$-D-glucosaminidase, $\beta$-D-glucosidase and Hageman factor. These enzymes retained $50 \%, 30 \%$ and $1 \%$ of their pre-incubation activities, respectively. Incubation at $\mathrm{pH} 5.0$ or above had little effect on any of the enzyme activities (data not shown).

\section{Effect of growth on $50 \%$ (v/v) FBS on the expression of enzyme activities}

Cultures were grown in CDM medium without glucose and supplemented with $50 \%(\mathrm{v} / \mathrm{v})$ FBS; $50 \%$ (v/v) FBS contained $0.52 \mathrm{mg}$ glucose $\mathrm{ml}^{-1}$. The inoculum for the cultures was centrifuged to pellet the cells and resuspended in a small volume of $50 \mathrm{mM}$ potassium phosphate buffer $\mathrm{pH} 7.5$ prior to inoculation into the batch culture vessel. Culturing in FBS was repeated three times and a representative growth curve is shown in Fig. 2. Two hours after inoculation, the culture $\mathrm{OD}_{600}$ had reached 0.57 and no glucose could be detected in the culture supernatant. The culture optical density then fell to an $\mathrm{OD}_{600}$ of $0 \cdot 25$ after $24 \mathrm{~h}$. The viable count, which had increased from $3.0 \times 10^{8}$ c.f.u. $\mathrm{ml}^{-1}$ at inoculation to $1.4 \times 10^{9}$ c.f.u. $\mathrm{ml}^{-1}$ at $2.5 \mathrm{~h}$, also declined until at $24 \mathrm{~h}$ it was $3.0 \times 10^{8}$ c.f.u. $\mathrm{ml}^{-1}$. However, over the next $92 \mathrm{~h}$ the culture $\mathrm{OD}_{600}$ increased to 0.95 while the viable count declined slightly to $7 \cdot 2 \times 10^{7}$ c.f.u. $\mathrm{ml}^{-1}$ (Fig. 2). Centrifugation of culture samples and examination by Gram staining and light microscopy revealed that a fibrous precipitate was being formed in the culture. The precipitate had little solubility in $50 \mathrm{mM}$ potassium phosphate buffer $\mathrm{pH} 7.5$ or deionized water.

The precipitate was separated from the majority of $S$. gordonii cells (as observed by light microscopy) by lowspeed centrifugation $\left(500 \mathrm{~g}, 22^{\circ} \mathrm{C}, 5 \mathrm{~min}\right)$ and was washed six times with $50 \mathrm{mM}$ Tris/ $\mathrm{HCl}$ buffer $\mathrm{pH} 7.5$ to remove serum components. The composition of the washed precipitate was examined by SDS-PAGE following dissolution by boiling in SDS-PAGE sample buffer with $5 \%$ (v/v) 2-mercaptoethanol for $10 \mathrm{~min}$. Following centrifugation, the sample was separated on duplicate $10 \%$ SDS-PAGE gels and either stained with Coomassie blue for protein or with PAS stain to detect carbohydrate (data not shown). Analysis of the proteins present in the SDS-PAGE gel of the precipitate indicated that it consisted of serum components. PAS staining indicated that carbohydrate moieties of the serum glycoproteins were still detectable with no obvious differences between serum and the precipitate. To determine if residual fibrinogen was also contributing to the precipitate by forming fibrin, FBS was incubated with $2 \mathrm{U}$ thrombin at $37^{\circ} \mathrm{C}$ for $48 \mathrm{~h}$. No coagulation or precipitate was formed, indicating that there was no residual fibrinogen in the FBS (data not shown).

\section{Effect of FBS on enzyme activities in late-stationary phase}

Cell-associated specific enzyme activities in FBS cultures (Table 3) were initially increased (at $2.5 \mathrm{~h}$ and $5.5 \mathrm{~h}$ ) from those detected at inoculation. However, over the extended time period of the culture, enzyme activities were generally reduced, though not significantly (Table $3)$. Cell-associated enzyme activities were not significantly different from those activities found in cultures grown at $\mathrm{pH} 7 \cdot 5$ on $\mathrm{CDM}$ when compared with any time point in the FBS culture.

Analysis of the enzyme total activities indicated that $\beta$-Dglucosidase, plasmin and $\mathrm{Xa}$ activities were not detected 
Table 3. Cell-associated enzyme specific activities [nmol $\left.\mathrm{h}^{-1}(\mathrm{mg} \text { protein })^{-1}\right]$ of $\mathrm{S}$. gordonii $\mathrm{FSS} 2$ grown on $50 \% \mathrm{FBS}$, $\mathrm{pH}$ $7 \cdot 5$

ND, Not detected $\left[<2 \mathrm{nmol} \mathrm{h}^{-1}(\mathrm{mg} \text { protein })^{-1}\right]$. Values are the mean of two assays; replicates all showed less than twofold difference.

\begin{tabular}{|c|c|c|c|c|c|c|c|}
\hline Enzyme & $\mathbf{0 ~ h}$ & $2 \cdot 5 \mathrm{~h}$ & $5 \cdot 5 \mathrm{~h}$ & $24 \mathrm{~h}$ & $72 \mathrm{~h}$ & $96 \mathrm{~h}$ & $116 \mathrm{~h}$ \\
\hline$\beta$-D-Galactosidase & ND & $48 \cdot 5$ & $56 \cdot 2$ & $20 \cdot 9$ & $15 \cdot 5$ & $6 \cdot 7$ & $3 \cdot 5$ \\
\hline$N$-Acetyl- $\beta$-D-glucosaminidase & $6 \cdot 2$ & $704 \cdot 5$ & $677 \cdot 2$ & $235 \cdot 8$ & $140 \cdot 5$ & $78 \cdot 1$ & $42 \cdot 3$ \\
\hline$N$-Acetyl- $\beta$-D-galactosaminidase & ND & $149 \cdot 9$ & $132 \cdot 0$ & $49 \cdot 5$ & $21 \cdot 0$ & $12 \cdot 6$ & $8 \cdot 3$ \\
\hline$\beta$-D-Glucosidase & ND & $32 \cdot 1$ & $89 \cdot 4$ & $35 \cdot 2$ & $14 \cdot 7$ & $13 \cdot 2$ & $7 \cdot 7$ \\
\hline Thrombin & ND & $23 \cdot 9$ & $68 \cdot 7$ & $183 \cdot 0$ & $165 \cdot 7$ & 130 & $73 \cdot 1$ \\
\hline Plasmin & $2 \cdot 9$ & $8 \cdot 4$ & $13 \cdot 2$ & $4 \cdot 1$ & ND & ND & ND \\
\hline Kallikrein & $16 \cdot 9$ & ND & $2 \cdot 6$ & $\mathrm{ND}$ & $\mathrm{ND}$ & $\mathrm{ND}$ & ND \\
\hline Hageman & 1403 & $1130 \cdot 0$ & $1156 \cdot 3$ & $1055 \cdot 4$ & $1818 \cdot 4$ & $1214 \cdot 5$ & $779 \cdot 2$ \\
\hline Collagenase & $5 \cdot 0$ & 6.9 & $3 \cdot 1$ & $20 \cdot 3$ & $29 \cdot 2$ & $24 \cdot 4$ & $10 \cdot 5$ \\
\hline $\mathrm{Ca}$ & ND & $13 \cdot 1$ & $9 \cdot 4$ & $8 \cdot 2$ & $18 \cdot 3$ & $\mathrm{ND}$ & $9 \cdot 9$ \\
\hline $\mathrm{Xa}$ & $2 \cdot 2$ & ND & $\mathrm{ND}$ & ND & ND & ND & $\mathrm{ND}$ \\
\hline Chymotrypsin & $2 \cdot 2$ & $11 \cdot 9$ & $5 \cdot 8$ & $13 \cdot 8$ & $18 \cdot 3$ & $14 \cdot 9$ & $16 \cdot 6$ \\
\hline
\end{tabular}

Table 4. Culture-supernatant enzyme total activities [nmol h-1 $(100 \mathrm{ml} \text { culture })^{-1}$ ] for $\mathrm{S}$. gordonii FSS2 grown on $50 \%$ (v/v) FBS, pH 7.5

ND, Not detected $\left[<2 \mathrm{nmol} \mathrm{h}^{-1}(100 \mathrm{ml} \text { culture })^{-1}\right]$. Values are the mean of two assays; all replicates showed less than twofold difference except where indicated.

\begin{tabular}{|c|c|c|c|c|c|c|c|}
\hline Enzyme & $\begin{array}{c}0 \mathrm{~h} \text { [Uninoculated } \\
\mathbf{5 0} \%(\mathrm{v} / \mathrm{v}) \mathrm{FBS}]\end{array}$ & $2 \cdot 5 \mathrm{~h}$ & $5.5 \mathrm{~h}$ & $24 \mathrm{~h}$ & $72 \mathrm{~h}$ & $96 \mathrm{~h}$ & $116 \mathrm{~h}$ \\
\hline$\beta$-D-Galactosidase & ND & ND & ND & $120 \cdot 6$ & $181 \cdot 3$ & $209 \cdot 1$ & $168 \cdot 5$ \\
\hline $\begin{array}{l}N \text {-Acetyl- } \beta \text {-D- } \\
\text { glucosaminidase }\end{array}$ & ND & $443 \cdot 3$ & $833 \cdot 8$ & $2752 \cdot 2$ & $3313 \cdot 8$ & $3733 \cdot 7$ & $4064 \cdot 1$ \\
\hline $\begin{array}{l}N \text {-Acetyl- } \beta \text {-D- } \\
\text { galactosaminidase }\end{array}$ & ND & $58 \cdot 6$ & $116 \cdot 4$ & $574 \cdot 9$ & $645 \cdot 0$ & $756 \cdot 3$ & $732 \cdot 8$ \\
\hline$\beta$-D-Glucosidase & ND & ND & ND & $\mathrm{ND}$ & $\mathrm{ND}$ & ND & $\mathrm{ND}$ \\
\hline Thrombin & $5 \cdot 7$ & $32 \cdot 0$ & $58 \cdot 1$ & $82 \cdot 3$ & $123 \cdot 6$ & $171 \cdot 6$ & $177 \cdot 2$ \\
\hline Plasmin & ND & $\mathrm{ND}$ & ND & $\mathrm{ND}$ & ND & ND & $\mathrm{ND}$ \\
\hline Kallikrein & ND & ND & ND & ND & ND & $4 \cdot 1(2 \cdot 2-5 \cdot 9)$ & ND \\
\hline Hageman & $9 \cdot 8$ & $995 \cdot 1$ & $2579 \cdot 6$ & $7636 \cdot 0$ & $8445 \cdot 1$ & $10269 \cdot 0$ & 12531 \\
\hline Collagenase & ND & $6 \cdot 8(0 \cdot 0-13 \cdot 6)$ & $39 \cdot 8$ & $137 \cdot 8$ & $170 \cdot 2$ & $222 \cdot 3$ & $211 \cdot 0$ \\
\hline $\mathrm{Ca}$ & ND & ND & $15 \cdot 3$ & $14 \cdot 1(7 \cdot 8-20 \cdot 4)$ & ND & ND & $\mathrm{ND}$ \\
\hline $\mathrm{Xa}$ & ND & ND & ND & ND & ND & $\mathrm{ND}$ & $\mathrm{ND}$ \\
\hline Chymotrypsin & ND & ND & ND & $35 \cdot 6$ & 51.9 & $107 \cdot 3$ & $115 \cdot 6$ \\
\hline
\end{tabular}

at any time in the culture supernatant (Table 4). Of those activities detected, there was a significant increase in both glycosidase and peptidase activities between $0 \mathrm{~h}$ and $96 \mathrm{~h}(P<0.001) ; 0 \mathrm{~h}$ and $116 \mathrm{~h}(P<0.01) ; 2.5 \mathrm{~h}$ and $96 \mathrm{~h}(P<0.01) ; 2.5 \mathrm{~h}$ and $116 \mathrm{~h}(P<0.05)$ (Table 4$)$. When compared with the $\mathrm{pH} 7 \cdot 5$ cultures grown on CDM, FBS culture-supernatant activities were significantly increased at all time points after $24 \mathrm{~h}(P<0 \cdot 05)$.

\section{DISCUSSION}

S. gordonii is found as a normal commensal organism in the oral cavity and as an opportunistic pathogen in thrombotic vegetations on the heart valve. To be able to survive and grow in these two very different conditions it must be able to adapt its physiology to the respective environments. The oral cavity, for instance, is subject to periodic high loadings of dietary carbohydrate with subsequent low $\mathrm{pH}$ as the carbohydrate is metabolized to its acidic by-products. In contrast, between meal times and at night during sleep, easily metabolizable carbohydrate is virtually absent and a more neutral $\mathrm{pH}$ occurs due to buffering by saliva. Under these conditions the bacterium must scavenge nutrients from salivary components. This study has shown that under these latter conditions glycosidase and peptidase enzymes are up-regulated. Growth of S. gordonii FSS2 at low $\mathrm{pH}$ showed that an acidic environment decreased the 
production of both cell-associated protein and culturesupernatant protein. This observation was paralleled by the reduction of glycosidase and peptidase activities at low $\mathrm{pH}$.

Previous chemostat studies showed that glucose, although present at a low level $\left(9-15 \mu \mathrm{g} \mathrm{ml}^{-1}\right)$, was still detectable in all steady-state conditions (Mayo et al., 1995). In the current batch-culture studies, no glucose was detectable by stationary phase. When grown under glucose-excess/nitrogen-limited conditions, it was noted that glycosidase expression was significantly repressed whereas peptidase expression was virtually unchanged. This suggested that the presence of glucose was repressing the expression of the glycosidase enzymes. Catabolite repression of glycosidases by glucose in $S$. oralis has been previously reported (Rafay et al., 1996).

In contrast to the oral environment, in an IE vegetation large fluctuations in carbohydrate concentration and therefore in acidity are unlikely to occur. The $\mathrm{pH}$ of the local environment would therefore be expected to be more stable with a near-neutral $\mathrm{pH}$ similar to that in the oral cavity in the absence of dietary carbohydrate. Even though it is not known what nutrients are available to streptococci in a platelet fibrin vegetation, serum glucose is present in the blood at $1 \mathrm{mg} \mathrm{ml}^{-1}$. The relative availability of blood glucose to bacteria in a vegetation is not known; however, transmission electron microscopic images of sections through staphylococcal IE vegetations show densely packed bacterial cells embedded in an amorphous fibrous matrix, probably comprising fibrin, platelets and other host and bacterial products, with no bacteria visible on the surface (Marrie et al., 1987; Ferguson et al. 1986). When the surface of a damaged vegetation is examined (Marrie et al., 1987), the exposed subsurface shows large numbers of bacteria covered by a 'flocculent material' which has been described as being similar to the exopolysaccharide material found by Mills et al. (1984). Durack \& Beeson (1972) have also reported that bacteria near the surface of the vegetation are metabolically active whilst those buried deeper are metabolically inactive. These findings would imply that those metabolically active bacteria in the surface layers of the vegetation are exposed to glucose from blood. However, the nutritional status of the bacteria in the bulk of the vegetation is unknown but they may be existing in near-starvation conditions. The increased expression of glycosidases at $\mathrm{pH} 7.5$ and when also cultured in the presence of serum indicate an adaptive response to the available nutrients in the environment. In our studies, serum clearly up-regulates the synthesis and secretion of the glycosidases by $S$. gordonii that would be required for acquisition of oligosaccharides from host sources.

This study also showed that $S$. gordonii is able to regulate specific peptidase activities involved in clot formation [i.e. thrombin, Hageman factor (lysine peptidase) and $\mathrm{Xa}$ ] as well as clot dissolution (i.e. plasmin, kallikrein and $\mathrm{Ca}$ ). Hageman factor was the most abundant activity found under any condition. It was the least affected by $\mathrm{pH}$ and was continuously accumulated in the culture supernatant when $S$. gordonii was grown on FBS. The ability of $S$. gordonii FSS2 to synthesize enzymes similar to those that promote the formation of clots would amplify the effect of clot formation already stimulated by the platelet-aggregating ability of this IE strain when it first enters the bloodstream (Manning et al., 1994a, b). Conversely, activities that promote clot dissolution would clearly assist in the penetration and release of potential nutrients into the clot in close proximity to the bacteria. It is perhaps pertinent to speculate that clot dissolution on a larger scale may also assist in the dissemination of an IE infection to other sites in the body. IE vegetations are known to be friable and to fragment, spreading the infection to other sites where they cause abscesses in organs such as the lungs, liver and kidneys (Ferguson et al., 1986).

In conclusion, the glycosidases and peptidases of $S$. gordonii have been shown to be up-regulated in neutral $\mathrm{pH}$ environments and in the presence of serum. The increased expression of these enzymes would greatly assist $S$. gordonii in acquiring nutrients, particularly in the environment of the IE vegetation, but also in 'healthy' dental plaque or between meal times when it relies on intrinsic sources of nutrients for survival.

\section{ACKNOWLEDGEMENTS}

This work was supported by grants to D. W.S.H. and N.A. J. from the Australian National Health and Medical Research Council (Project Grant No. 970724) and the Australian Dental Research Foundation Inc.

\section{REFERENCES}

Beighton, D., Homer, K. A. \& Kelley, S. (1995). The production of protease activities by Streptococcus oralis strains isolated from endocarditis. Microb Ecol Health Dis 8, 213-218.

Durack, D. T. \& Beeson, P. B. (1972). Experimental bacterial endocarditis. II. Survival of bacteria in endocarditis vegetations. Br J Exp Pathol 53, 50-53.

Ferguson, D. L., McColm, A. A., Ryan, D. M. \& Acred, P. (1986). A morphological study of experimental staphylococcal endocarditis and aortitis. II. Inter-relationship of bacteria, vegetation and cardiovasculature in established infections. Br J Exp Pathol 67, 679-686.

Ford, I. \& Douglas, C. W. I. (1997). The role of platelets in infective endocarditis. Platelets 8, 285-294.

Herzberg, M. C. (1996). Platelet-streptococcal interactions in endocarditis. Crit Rev Oral Biol Med 7, 222-236.

Herzberg, M. C. \& Meyer, M. W. (1996). Effects of oral flora on platelets: possible consequences in cardiovascular disease. $J$ Periodontol 67, 1138-1142.

Herzberg, M. C., MacFarlane, G. D., Ke Gong, Armstrong, N. N., Witt, A. R., Erickson, P. R. \& Meyer, M. W. (1992). The platelet interactivity phenotype of Streptococcus sanguis influences the course of experimental endocarditis. Infect Immun 60, 4809-4818.

Homer, K. A., Kelley, S., Hawkes, J., Beighton, D. \& Grootveld, M. C. (1996). Metabolism of glycoprotein-derived sialic acid and 
$\mathrm{N}$-acetylglucosamine by Streptococcus oralis. Microbiology 142, 1221-1230.

Ke Gong, Ouyang, T. \& Herzberg, M. C. (1998). A streptococcal adhesion system for salivary pellicle and platelets. Infect Immun 66, 5388-5392.

Laemmli, U. K. (1970). Cleavage of structural proteins during the assembly of the head of bacteriophage T4. Nature 227, 680-685.

Lowrance, J. H., Hasty, D. L. \& Simpson, W. A. (1988). Adherence of Streptococcus sanguis to conformationally specific determinants in fibronectin. Infect Immun 56, 2279-2285.

Manning, J. E., Geylin, A. J., Ansmits, L. M., Oakey, H. J. \& Knox, K. W. (1994a). A comparative study of the aggregation of human, rat and rabbit platelets by members of the Streptococcus sanguis group. J Med Microbiol 41, 10-13.

Manning, J. E., Hume, E. B. H., Hunter, N. \& Knox, K. W. (1994b). An appraisal of the virulence factors associated with streptococcal endocarditis. J Med Microbiol 40, 110-114.

Marrie, T. J., Cooper, M. B. \& Costerton, J. B. (1987). Ultrastructure of cardiac bacterial vegetations on native valves with emphasis on alterations in bacterial morphology following antibiotic treatment. Can J Cardiol 3, 275-280.

Mayo, J. A., Zhu, H., Harty, D. W. S. \& Knox, K. W. (1995). Modulation of glycosidase and protease activities by chemostat growth conditions in an endocarditis strain of Streptococcus sanguis. Oral Microbiol Immunol 10, 342-348.

Meyer, M. W., Ke Gong \& Herzberg, M. C. (1998). Streptococcus sanguis-induced platelet clotting in rabbits and hemodynamic and cardiopulmonary consequences. Infect Immun 66, 5906-5914.
Mills, J., Pulliam, L., Dall, L., Marzouk, J., Wilson, W. \& Costerton, J. W. (1984). Exopolysaccharide production by viridans streptococci in experimental endocarditis. Infect Immun 43, 359-367.

Oakey, H. J., Harty, D. W. S. \& Knox, K. W. (1995). Enzyme production by lactobacilli and the potential link with infective endocarditis. J Appl Bacteriol 78, 142-148.

Pitty, L. J. \& Jacques, N. A. (1989). Dissimilar effects of $\mathrm{Na}^{+}$and $\mathrm{K}^{+}$on the promotion of glucosyltransferase secretion in Streptococcus salivarius. J Gen Microbiol 135, 1431-1439.

Rafay, A. M., Homer, K. A. \& Beighton, D. (1996). Effect of mucin and glucose on proteolytic and glycosidic activities of Streptococcus oralis. J Med Microbiol 44, 409-417.

Terleckyj, B., Willet, N. P. \& Shockman, G. D. (1975). Growth of several cariogenic strains of oral streptococci in a chemicallydefined medium. Infect Immun 11, 649-655.

Vriesema, A. J. M., Dankert, J. \& Zaat, S. A. J. (2000). A shift from oral to blood $\mathrm{pH}$ is a stimulus for adaptive gene expression of Streptococcus gordonii $\mathrm{CH} 1$ and induces protection against oxidative stress and enhanced bacterial growth by expression of msrA. Infect Immun 68, 1061-1068.

Whiley, R. A. \& Beighton, D. (1998). Current classification of the oral streptococci. Oral Microbiol Immunol 13, 195-216.

Wittenberger, C. L., Beaman, A. J. \& Lee, L. N. (1978). Tween 80 effect on glucosyltransferase synthesis by Streptococcus salivarius. J Bacteriol 133, 231-239.

Received 21 January 2000; revised 14 April 2000; accepted 16 May 2000. 